\title{
CRIMEAN WAR AND ESTABLISHING OF PUBLIC HEALTH SYSTEM IN GREAT BRITAIN
}

\author{
E.Sklyarova \\ Rostov State Medical University. Rostov-on-Don, Russian Federation \\ science-almanac@mail.ru
}

\begin{abstract}
Crimean War of 1853 - 1856 is a factor of important socio-political and socio-medical reforms. Study of these cases is characterized as interdisciplinary. At the edge of Crimean War Great Britain press highlighted aspiration of the empire tocapture russian territories of Black sea region, also reforms and work of E.Chadwick, founder of public health system, were criticized, he was wanted to be away from members of parliament and London oligarchs due to his extreme reforms and British corruption. The article representsseveral effects of Crimean War, itsmeaning forestablishing of public health system in Great Britain, reforms and pioneering work of Edwin Chadwick, Florence Nightingale, also brought up issues of urbanization, pauperism, migration, corruption, health care of cities and army. Developing ideas ofutilitarianism and benthamism, E.Chadwickproved advantage ofestablishing of public health system, centralization of cities administration, unticorruption efforts. His unduedismissal was passing during Crimean War, preparation for abolition of serfdom andkeeping of autocracy in Russia. In this period innovation seemed inconsistent to british peopleconsidering century principles forlocal government andnonintervention todomestic affairs of kingdom. Russia and its Black sea regions, which have becomewar objective for British Empire, were namedas corrupted country by English press. But corruption in Great Britain, unique position of members of parliament and London oligarchs have become reasons for dismissal of founder of public health system in Great Britain. After Crimean War in cities there was a problem of social assistance for widows, street children, families with many children, epidemics. Issues of mortality, healthcare of cities and army also became an object of parliamentary debates, requiring constant interference of the government, establishing of social policy. Fresh impetus and acceptance of establishing of public health system, as well as asocial policy in Great Britain have become evident in period of Crimean War after successful public activity of sister of Mercy F.Nightingale, whoaddressing the House with reports onmorbidity level in army, highlighting existence of these social problems and peacetime in Great Britain and Black Sea regions.
\end{abstract} nization.

Key words: Crimean War, public health, corruption, E. Chadwick, F. Nightingale, social policy, urba-

Crimean War of 1853 - 1856 became a factor for a number of most important sociopolitical and socio-medical reforms in Russia and Great Britain in the XIX century. Investigation of Crimean War effects have became particularly relevant in the XXI century after demise of the Soviet Union and the entry of the Crimea into Russia. In current studies, a scientific analysis of these problems is characterized as "interdisciplinary" [5].

In the middle of the nineteenth century, at the edge of Crimean War, the weekly English magazine "The Economist", cynically welcoming the resignation of the leading social reformer of Great Britain, wrote "there is one nation in Europe where he would be invaluable, where his research, his desire to reach the end, and conscientious diligence, conviction in achieving the goal, freedom of action would perform the most salutary revolution; Where almost everything requires changes, where people are slaves and voluntary slaves ... In the war we are involved in, we hope to destroy Kronstadt, capture Sevastopol, revolutionize Georgia ... but when we do this, we sincerely believe that we will give Russia the equivalent of everything what we conquer, and in case of peace, we will make her a gift in the person of Mr. Chadwick, in order to reform her corrupted and overgrown bureaucracy" [17]. 
Edwin Chadwick -is a famous social reformer of the XIX century, he was one of the founders of the public health system, developer of new principles of social policy in the UK $[14 ; 7$, p. 103-108]. His work for a long time causedfierce disputes and a subjective stereotype of perception. In the middle of XX century in the period of creation of the National Health System, a reassessment of his historical role began, noting that the General Council of Healthcare, created by him, is the predecessor of the Ministry of Health in Britain. At the end of the XX century E. Chadwick's workwas considered as a factor of the formation of the "government prosperity"[13].

Developing the ideas of "benthamism" [7, p. 105], E. Chadwick contributed to acceptance of new poor law and the first act for public health in Britain [8]. In national historical research E. Chadwick was called a "gift of Russia or Britain" for the fact that at the edge of Crimean War and hatred to Russia, desire of Britain to capture Russian Black Sea territories from the reformer, due tohisextreme reforms and British corruption, was wanted to get rid of by members of parliament and London oligarchs [6; 7, p. 103-105].

Being the founder of the public health system, E. Chadwick became one of the developers of the first "Act of Public Health, 1848", a new poor law, migration charts and enumeration, establishment of the institution of officers of health and mandatory payment for social workers. Developing the ideas of utilitarianism and benthamism, he proved benefits of taxation reform, centralization of city administration, and anticorruption efforts. Legally E. Chadwick was not the first head of the new authorities, but hemanaged them indeed. In addition, for the first time in England, for this work, he achieved permanent salary. "The London Gazette" issued by the governmentannounced on September 26, 1848, that Queen Victoria had appointed Lord Ashley and E. Chadwick as members of the General Council of Health [18]. Lord Morpeth, Her Majesty, the first member of "Commission for affairs of forests, hunting land, income from landed lands, public works and buildings", was automatically confirmed as the President of the General Council of Health. Later this post depended solely on the belonging to a party of head of this agency, disregarding professional knowledge and skills in sphere of public health. According to the first "Act of Public Health dated 1848", new public institution became center of establishment of the health care system in Britain.

However, new management sphere, had becoming paid, was arena of ambitions. On the 5th of August, 1854, at the edge of Crimean War, "The Economist" cynically criticized E. Chadwick, calling him "a precious stone that turned out to be in a wrong place," a "bureaucrat," emphasizing British hard-and-fast guidelines for management. The newspaper specified that he would had been invaluable in Austria, France, Prussia, as well as in Russia, where "people do not do anything for themselves", where there is no self-government and everything is being done for them by governments [17].

Unearneddismissal of Edwin Chadwick wasduring Crimean War, preparation of the abolition of serfdom and the preservation of autocracy in Russia. It was during that period, that the reformer's work seemed to britishpeople incompatible with the age-old principles of local government and non-interference in internal affairs of the kingdom. Russian Empire and its Black Sea regions, becoming object of war in the foreign policy of British Empire, was called a corrupted countryin English press. However, corruption in Britain, unique position of members of parliament and oligarchs of England, became reasons for dismissal of E. Chadwick. For a long time, even name of the creator of public health and social policy system of Britain was not included in "History of Medicine" textbooks in Britain and Russia due to corruption, taking its rightful place in the 21 st century [4, 6, p. 185-187]. After Napoleonic wars and Crimean War, the problem of social support for widows, street children, nurses, former combatants, and families with many children was acute in cities of Great Britain and Russia. Population increase, epidemics, growth of social benefits, taxes and expenses, problems of the death rate of population, health carein cities and army be- 
came the object of parliamentary debates, demanding constant intervention of government. These social problems became even more relevant during urbanization period, as well as during Crimean War. Due to a fast growth of population of the United Kingdom, as well as increase ofquantity of widows and orphans, there wasa development of social policies in the country. "The Poor Man`s Guardian", "The Economist", "Builder" criticized corruption and poor laws, emphasizing the need for social reforms and public health care[19].

The new impetus for establishment of public health and social policy in Great Britain became evident during Crimean War after successful public activities of a famous sister of mercy, nurse and public character Florence Nightingale. She was not a member of parliament, or member of a party, because a women did not have legislative and electoral rights for this in Britain at that time. They did not pay taxes and were dependent on their families and men. During the years of Crimean War, reporting on the mortality rate in the army in British Parliament, this woman specified existence of this important socio-medical problem also in peacetime in the cities of the country.

Crimean War made "The Lady with the Lamp" respected by soldiers of Russian and British armies, as well as public and medical spheres of many Black Sea region countries. As result of the reforms, the death rate in hospitals in the UK, Russia, and Turkey decreased. The next task was creation of the Royal Commission of Health care of the Army, reorganization of the medical service and statistics. In order to ensure the parliament it is a need for army health care, she undertook a statistical study, and was elected a member of Royal Statistical Society in 1859.

With help of the Minister for War, Lord Herbert (son of Russian countessEkaterinaVorontsova, grandson of ambassador to BritainSemyonRomanovichVorontsov), she achieved beginning of solving the problem of army's health care-equipment of hospitals with ventilation systems and establishment of medical statistics. With help of English doctor and statistician U. Farrshe developed a form of statistical reports for hospitals. The document was approved by the International Congress of Statisticians in 1860 in London. She presented her experience in books analyzing problems of nursing care for wounded, management effectiveness of naval hospitals, and professional education of hospital personnel [11,12]. F. Nightingale opened a school for sisters of mercy at the hospital in London in 1860. Graduates of the school opened similar institutions at hospitals in Britain, Sweden, America [7; 6, p. 184-188].

This outstanding woman "considered herself as a liberal." The British government highly appreciated the outstanding work of F. Nightingale, awarding her with the Royal Red Cross in 1883. The famous nurse and public character, supporting the social reforms and ideas of E. Chadwick after the end of Crimean War, came forward with proposals to introduce an institute of sisterhood and medical care not only in army, but also for poor, women and children in the country's cities [10]. The object for social reforms, new level of financing and inspection of the government were to become hospitals, children's institutions, the sanitary condition of army and cities.

These sociopolitical and economic tasks were particularlytopical for providing the military strengthin Black Sea countries, as well as in growing industrial cities and ports of Britain - London, Liverpool, Manchester, Leeds, Croydon, Bradford, Sheffield, Wolverhampton and many others in the era of urbanization. The leaders of social reforms in the era of Crimean War and urbanization were E. Chadwick, F. Nightingale, S. Smith, W. Farr, J. Simon and others. Most of them were public characters or doctors.Practical reforms consideringmortality reduce and urban health care were initiated on the basis of statistical data, jointly with the Parliament, the government of Lord Palmerston, Queen Victoria, periodical press, the General Council of Health, the Chamber of the General Registrar, military hospitals. 
A comparative analysis of social reforms in Russia and the United Kingdom in the first half of the nineteenth century proves that ideas of social reforms were considered in the context of population well-being, taxes and benefits, public health care, determining the establishment of social policy in Russia and Britain. E. Chadwick, F. Nightingale, the committee of the poor law, the General Council of Health "specified the need for a complete transformation of state policy, forcing the parliament to begin its revision" [1].

The ideas of Edwin Chadwick and F. Nightingale considering the need forprevention of mortality, diseases, as well as the centralization of health management, government intervention in resolving the social problems of cities and the army were radical at that time. Chadwick's proposals for state in which utilities (water supply, gas supply, burial, ventilation) should belong to the state, being a public affair, rather than a commercial one, caused displeasure of some members of the parliament and owners of private enterprises. The need for change the management system was not initially perceived by contemporaries as a blessing. Socio-medical ideas were regarded to as an attack on privileges and private property, and social reforms as a possible end to the established system of income generation.However, during Crimean War social reforms became a social need. "The redistribution of influence spheres, management and property was carried out through local and national reforms in terms of industrialization and urbanization" [6], the end of Crimean War, as well as redistribution and nationalization of private property of public importance in the cities of Great Britain and Ireland.

The problem of death rate increase of population of the United Kingdom during Crimean War, as well as the epidemic affected all social strata of the population, as well as members of the royal family, stressing "the problem of life expectancy, the need for the formation of scientific and medical societies, health of army and city. All these social changes have become an object of parliamentary research, a factor of subsequent social reforms, development of health care system and social policy of the United Kingdom " [2].

Thus, during Crimean War, socio-medical reforms, public health, and problem of corruption became a focus of attention of social reformers, parliament and press of Great Britain. The periodicals reflected Britain's plans to seize the Black Sea area - Crimea, Georgia, including Sevastopol, as well as the negative attitude to Russia and social and medical reforms in Britain itself. Leaders of social reforms in the era of Crimean War in Britain were E. Chadwick, F. Nightingale, W. Farr and others. Reforms to reduce mortality were initiated jointly with the parliament, the periodical press, the General Council of Health, military hospitals and hospitals in the UK. Gradually, new principles of social reforms were developed: prevention of population mortality, payment of social workers, utilitarianism and centralization of management. The periodical press, becoming a means of public control, simultaneously contributed to the undeserved persecution of the reformers, the aggravation of relations between Russia and Britain. The Crimean war defined a new direction of social reforms, a revision of the parochial policy for the charity of the poor, health care of cities and army. The new principles of work of the General Council of Health and the activities of E. Chadwick, due to corruption, initially did not receive a public recognition. Corruption caused dismissal of Edwin Chadwick, initial rejection of a number of socio-medical reforms. The need to overcome corruption in the era of urbanization was underlined by the press in course of formation of the public health system of Great Britain. A new impetus for the emergence of social policy and public health became evident after $F$. Nightingale's successful social work during Crimean War. Supporting E. Chadwick reforms after Crimean War, the reformers have made an introduction of a system of medical care, not only in hospitals and armies of Black Sea region, but also health of cities. 


\section{Лumepamypa}

1. Гутиева М.А., Склярова Е.К.Сравнительный анализ социальных реформ России и Великобритании в первой половине XIX века // Гуманитарные и социальные науки. 2015. № 1.

2. Макарова В.Н., Склярова Е.К., Чубарян В.Т. Викторианская урбанизация и проблема смертности и здравоохранения в Великобритании // Гуманитарные и социально-экономические науки. 2014. № 2.

3. Склярова Е. К. Урбанизация, социальная реформа и здравоохранение Великобритании в первой половине XIX века. Ростов н/Д: ИПО ПИ ЮФУ, 2011.

4. Склярова Е.К. Жаров Л.В., Камалова О.Н. История медицины: краткий курс. Ростов н/Д, 2014.

5. Склярова Е.К.Здравоохранение и викторианская урбанизация: основные направления междисциплинарных исследований // Гуманитарные и социальные науки. 2014. № 2.

6. Склярова Е.К., Камалова О.Н. Сравнительные аспекты становления здравоохранения в Англии, Шотландии, Ирландии и России в XIX в // Роль медицинских вузов в подготовке медицинских кадров: исторические аспекты материалы Всероссийской научно-практической конференции, посвящённой открытию музея истории Иркутского государственного медицинского университета, в рамках празднования 355-летия города Иркутска. Иркутск, 2016.

7. Склярова Е.К., Камалова О.Н. Философские аспекты викторианского здравоохранения // Экономические и гуманитарные исследования регионов. 2015. № 1.

8. An Act for the Amendment and Better Administration of the Laws Relating to the Poor in England and Wales, 1834 // 4 \& 5 Will. IV. p. 76; Public Health Act, 1848 // $11 \& 12$ Vict. p.63.

9. Kamalova O.N., Andramonova V.V. Network society: problems of development and new forms of identity // Current problems of science: from theory to practice Materials of III National science-practical conference. 2016.

10. McDonald L. Florence Nightingale as A Social Reformer // History Today. - January 2016.

11. Nightingale F. Notes on Matters Affecting the Health, Efficiency and Hospital Administration of the British Army, L: Harrison and sons, 1858.

12. Nightingale F. Notes on Nursing: What It Is and What It Is Not. L., 59, Pall Mall, 1860.

13. Porter D., Porter R. The Ghost of Edwin Chadwick // The British Medical Journal. 1990. Aug. 4. No 301.; Klein R. Edwin Chadwick // In: Founders of the Welfare State / Ed. by P. Baker. L.,1986.

14. Principle of Legislation // Report from Commissioners for Inquiry into the Administration and Practical Operation of the Poor Laws // P.P. 1834. Vol. XXVII. Part II.

15. Sklyarova E.K. Comparative aspects of scientific research of the urbanization problem// Science almanac of Black Sea region countries. 2016. No 2. http://sciencealmanac.ru

16. Sklyarova E.K. The problems of migration during the period of urbanization in Great Britain and Ireland // Science almanac of Black Sea region countries. 2016. No 1. http://science-almanac.ru

17. The Economist. 1854. Aug. 5.

18. The London Gazette. 1848. Sept. 26.

19. The Poor Man's Guardian. 1833. March 2. P. 70 - 71; The Economist. 1854. Vol. XII. 7 Jan.; The Builder. 1852. Vol.10. May. P. 301. 


\section{References}

1. GutievaM.A., SklyarovaE.K.Comparative analysis of social reforms in Russia and Great Britainin the first half of XIX century/l The Humanities and social sciences.2015. No 1.

2. Makarova V.N., SklyarovaE.K., Chubaryan V.T. Victorian urbanizationand problem of mortality and health care in Great Britain // The Humanities and socio-economic sciences. 2014. No 2.

3. SklyarovaE. K. Urbanization, social reform and health care in Great Britain in the first half of XIX century. Rostov-on-Don, 2011.

4. SklyarovaE.K.ZharovL.V., KamalovaO.N.History of medicine: short course. Rostovon-Don, 2014.

5. SklyarovaE.K.Health care and victorian urbanization: main trends of interdisciplinary researches// Human and social sciences. 2014. No 2.

6. SklyarovaE.K., KamalovaO. N. Comparative aspectsof establishing of health care in England, Scotland, Ireland and Russia in XIX century // historical aspects materials of national research and training conference, dedicated to opening of museum of history of Irkutsk State Medical University, in the framework ofcelebration of 355 years of Irkutsk. Irkutsk, 2016.

7. SklyarovaE.K., KamalovaO. N. Philosophic aspects of Victorian health care// Economical and human researches of regions. 2015. No 1.

8. An Act for the Amendment and Better Administration of the Laws Relating to the Poor in England and Wales, 1834 // 4 \& 5 Will. IV. p. 76; Public Health Act, 1848 // 11 \&12 Vict.p.63.

9. Kamalova O.N., Andramonova V.V. Network society: problems of development and new forms of identity // Current problems of science: from theory to practice Materials of III National science-practical conference. 2016.

10. McDonald L. Florence Nightingale as A Social Reformer // History Today. - January 2016.

11. Nightingale F. Notes on Matters Affecting the Health, Efficiency and Hospital Administration of the British Army, L: Harrison and sons, 1858.

12. Nightingale F. Notes on Nursing: What It Is and What It Is Not. L., 59, Pall Mall, 1860.

13. Porter D., Porter R. The Ghost of Edwin Chadwick // The British Medical Journal. 1990. Aug. 4. No 301.; Klein R. Edwin Chadwick // In: Founders of the Welfare State / Ed. by P. Baker. L.,1986.

14. Principle of Legislation // Report from Commissioners for Inquiry into the Administration and Practical Operation of the Poor Laws // P.P. 1834. Vol. XXVII. Part II.

15. Sklyarova E.K. Comparative aspects of scientific research of the urbanization problem// Science almanac ofBlack Sea region countries. 2016. No 2. http://sciencealmanac.ru

16. Sklyarova E.K. The problems of migration during the period of urbanization in Great Britain and Ireland // Science almanac of Black Sea region countries. 2016. No 1. http://science-almanac.ru

17. The Economist. 1854. Aug. 5.

18. The London Gazette. 1848. Sept. 26.

19. The Poor Man's Guardian. 1833. March 2. P. 70 - 71; The Economist. 1854. Vol. XII. 7 Jan.; The Builder. 1852. Vol.10. May. P. 301. 